\title{
EFFECTIVENESS OF COLD COMPRESS AND LAVENDER AROMATHERAPY ON REDUCTION IN POSTPARTUM PERINEAL PAIN INTENSITY
}

\author{
Yuanita Syaiful $^{1}$, Lilis Fatmawati ${ }^{2 *}$, Siti Nur Qomariah ${ }^{3}$, Aidatur Runis ${ }^{4}$ \\ 1, 2,3,4 Universitas Gresik \\ Email*: $\underline{\text { lilisfatmawati13@gmail.com }}$
}

\begin{abstract}
Introduction: Every postpartum mother got a perineal wound and experience pain. This pain results in unpleasant effect such as fear of movement which can lead to problems such as sub uterine involution, unhealthy release of lochea, and postpartum bleeding. The purpose of the study was to determine effectiveness of cold compress and lavender aromatherapy on the reduction in postpartum perineal pain intensity. Methods: This study uses a QuasiExperiment method with a pre-post test design. 32 samples were divided into 16 cold compresses and 16 lavender aromatherapy. The independent variable is the supply of cold compresses and lavender aromatherapy. The dependent variable is postpartum perineal pain. Data collection with standard operating procedures (SOP) for cold compresses, and lavender aromatherapy and observation sheets with bourbonic pain scales. Analyzed using the Wilcoxon test to find out before and after, to determine the effectiveness of using the Mann Whitney test. Results : Wilcoxon Signed Rank Test $P=0.000$ which means there is a difference in pain intensity before and after cold compresses are given, As for the lavender aromatherapy variable, the value of $P=0.008$ means that there is a difference in pain intensity before and after lavender aromatherapy is given. Mann-Whitney U Test statistic shows that the significance value $P=0.077$, so there is no significant difference between giving cold compress and lavender aromatherapy to reduction in postpartum perineal pain intensity. Conclusions: Cold compresses and lavender aromatherapy can be used as nonpharmacological therapy in reducing the intensity of postpartum perineal pain.
\end{abstract}

Keywords: cold compress; lavender aromatherapy; perineal pain; postpartum

\section{INTRODUCTION}

Postpartum is the period after the release of the placenta until the reproductive organs recover as before pregnancy, and usually, the puerperium lasts for six weeks. Things that are often experienced by postpartum mothers and cause pain during the puerperium are injuries to the perineal area that occurs during labor (Sulistyawati, 2009). Perineal injury is defined as a tear that can occur due to spontaneous tears or episiotomy, which can be a gynecological problem in the future but can be corrected after delivery (Ai Yeyeh et al., 2010). Perineal pain is pain caused by tears that occur in the perineum, vagina, cervix, or uterus can occur spontaneously or as a result of manipulative actions in childbirth assistance (Prawirohardjo, 2009).

In the first few days after birth, the mother experiences moderate to severe pain that has early symptoms of decreased mobility and decreased ability to perform daily activities, difficulty sitting due to perineal pain can inhibit the initiation of breastfeeding which will affect the bond of mother and baby (Mulati and Susilowati, 2018). The effects of perineal pain are stress, traumatic, fear of injury, no appetite, insomnia and depression, so that postpartum mothers experience delayed mobilization, discomfort when sitting, standing walking and moving, so that it impacts on postpartum maternal resting disorders and delays in initial contact between mother and baby (Ambarwati and Diah, 2010).

A preliminary study conducted by researchers on December 25, 2018, in the puerperium of Muhammadiyah Gresik Hospital obtained data on physiological postpartum mothers of 10 mothers, and eight mothers experienced severe pain scale in the perineal area, two other mothers experienced mild pain. During this time, to deal with pain only with analgesic 
drugs (anti-pain). However, the effectiveness of cold compresses and lavender aromatherapy cannot be explained.

Almost $90 \%$ of the normal delivery process has a tear injury to the perineum (WHO, 2015). Perineal laceration in Asia is also a problem that is quite common in society; $50 \%$ of the incidence of perineal rupture in the world occurs in Asia. The prevalence of maternal women who suffer perineal injury in Indonesia in the age group of $25-30$ years is $24 \%$ while in mothers with ages 31-39 years by $62 \%$. In Indonesia, perineal laceration is experienced by $75 \%$ of mothers giving birth vaginally. In 2013 found that of a total of 1951 vaginal deliveries, $57 \%$ of mothers received perineal sutures $28 \%$ due to episiotomy and $29 \%$ due to spontaneous tears (Depkes, 2013). The results of the survey at Muhammadiyah Hospital Gresik obtained data on postpartum physiological mothers in September 2018 totaling 116 people, in October 124 people, in November 117 people. Some postpartum mothers experience different pains. Of 116 people, 58 people $(50 \%)$ experienced moderate pain, 48 people $(41 \%)$, and ten people (9\%) experienced mild pain. When labor occurs, cervical dilatation and distension of the uterine corpus stretch the lower uterine, and cervical segments and pain continue to the dermatome supplied by the spinal cord segment similar to the segment that receives nociceptive input of the uterus and cervix (Steen, et al, 2007). Tension and tissue tears during labor occur in the perineum and pressure on the perineal skeletal muscle, pain caused by superficial somatic structures are stimulated and described as sharp and localized pain, especially in areas supplied by the pudendal nerve (Kartika et al., 2015). Things that are often experienced by postpartum mothers include pain and discomfort in rupture suture wounds. The problem of mothers giving birth with rupture of the perineum until now still needs to be considered because it can cause dysfunction of the female reproductive organs, as a source of bleeding and the way in and out of infection which then causes death due to bleeding or sepsis (Ambarwati and Diah, 2010). Factors affecting perineal wound pain, there are External and Internal factors. External factors include knowledge, socioeconomic, maternal condition, nutrition and internal factors including age, vascularization, tissue management, bleeding, hypovolemia, local edema factors, nutritional status, oxygen deficits, drugs, smoking, obesity, and diabetes mellitus. Perineal pain can cause complications such as postpartum hemorrhage (Oliviera, et al., 2012).

Pain management has two methods,
namely pharmacological and nonpharmacological. Pharmacological pain relievers are pain relievers using chemical drugs, including inhalation analgesics, opioid analgesics, and regional anesthesia. At the same time, nonpharmacological methods are natural pain relief methods without the use of chemical drugs. Pain management with cold compresses is a method that can be applied to help comfort the puerperal mother to reduce pain because it can reduce blood flow to the injured area so as to reduce the risk of bleeding and edema, cold compresses cause analgesic effects by slowing down the speed of nerve delivery so that impulse pain that reaches the brain will be less (Judha et al., 2012). Cold compresses are used to relieve pain by slowing down the speed of nerve conduction, causing anxiety and working as a counterirritant. Providing a cold application action can reduce pain and increase healing. Cold application is related to the ability of nerve pain to slow down in channeling pain stimuli (Sulistyawati, 2009).

Aromatherapy is also used as an alternative treatment for non-pharmacologic pain. Various kinds of aromatherapy that can be used include sandalwood, basil, cinnamon, ylang, citrus, jasmine, clove, lavender, rose, jasmine. Currently, the treatment that is often used to reduce pain is complimentary aromatherapy 
therapy with lavender essential oil, because lavender has anti-convulsant, anti-depressant, anxiolytic, and soothing properties. When aromatherapy is inhaled, the active substance contained in it will stimulate the hypothalamus (pituitary gland) to secrete the endorphin hormone. Endorphins are known as substances that cause calm, relaxed, and happy. In addition, the active substances in the form of linalool and linalyl acetate contained in lavender have analgesic effects. Lavender aromatherapy containing linalyl acetate and linalool that is inhaled into the nose is captured by the olfactory bulb and then enters through the olfactory canal branching into two, lateral and non-medial sides. The aim of the study was to determine the effectiveness of cold compress and lavender aromatherapy on the reduction in postpartum perineal pain intensity.

\section{METHODS}

The research design used a Quasi Experiment with a pre-post-test design. The population in this study were all physiological postpartum mothers of 116 mothers. The samples in this study were 32 postpartum physiological mothers who were divided into two groups, the first group of 16 mothers were given cold compress intervention, the second group of 16 mothers was given the aroma intervention of lavender therapy. The sampling technique uses a non-probability type purposive sampling method with inclusion criteria: 1) normal postpartum mothers who are willing to be respondents; 2) postpartum mothers 18-35 years; 3) postpartum mothers with hospitalization for two days in the puerperium; 4) primiparous and multiparous postpartum mothers-5) postpartum mothers perineal injury degrees 1, 2, 3 and 4 .

The independent variables in this study were cold compresses and lavender aromatherapy, while the dependent variable was perineal pain in postpartum mothers. This research was conducted in the post-mortem room of Muhammadiyah Hospital Gresik in May - July 2019.

The first and second group before the intervention was given a pre-test in the form of observation of postpartum maternal perineal pain. But in the second group, the pre-test was done by means of mothers being asked to inhale the aroma of lavender therapy with the mother's position as comfortable as possible. Furthermore, the researchers gave an intervention in the form of cold compresses in the first group for 20 minutes twice a day with a temperature of $15^{\circ} \mathrm{C}$ for 2 days of postpartum perineal pain. In the second group, the researchers intervened in the form of lavender aromatherapy for 15 minutes twice a day by dripping $0.5 \mathrm{ml}$ of lavender aromatherapy into the tissue for two days of postpartum perineal pain. After the intervention, a post-test was carried out in the form of observation of postpartum maternal perineal pain in the two groups.

Independent Variables were Standard Operating Procedure for cold compresses and Standard Operating Procedure for lavender aromatherapy. Dependent variable postpartum perineal pain used an observation sheet and measured the level of pain with the Bourbanis scale (Ersila et al., 2019).

The analysis in this study used the Wilcoxon test to determine differences in the dependent variable before and after treatment with a significance level of $p<0.05$. The results of the normality test in the two groups A found that the value of $\operatorname{sig}=0.142$, while in group $B$ the value of sig $=0.253$ was obtained, meaning that the two groups with normal distribution had normal data distribution. Furthermore, compared to the effectiveness of cold compress and lavender aromatherapy given intervention using the Mann Whitney U Test $p<0.05$ means to find out the significance of the effectiveness of cold compresses and lavender aromatherapy to decrease the intensity of perineal pain in 
postpartum mothers in postpartum women at Hospital in Gresik.

This study was conducted through an ethical test from the education ethics commission in and from the hospital where the study was conducted. The results of the ethics prove that there is no need to oppose ethics that are violated.

\section{RESULTS}

Table 1 Characteristics of Respondents

\begin{tabular}{|c|c|c|c|c|}
\hline \multirow[t]{2}{*}{ Characteristics } & \multicolumn{2}{|c|}{ Cold compress $(n=16)$} & \multicolumn{2}{|c|}{ Lavender Aromatherapy $(n=16)$} \\
\hline & $\mathbf{N}$ & $\%$ & $\mathbf{N}$ & $\%$ \\
\hline \multicolumn{5}{|l|}{ Age } \\
\hline $18-25$ years & 6 & 37 & 5 & 31 \\
\hline $26-30$ years & 8 & 50 & 7 & 44 \\
\hline $31-35$ years & 2 & 13 & 4 & 25 \\
\hline \multicolumn{5}{|l|}{ Profession } \\
\hline Housewife & 7 & 44 & 10 & 63 \\
\hline Entrepreneur & 0 & 0 & 0 & 0 \\
\hline Private & 9 & 56 & 5 & 31 \\
\hline Civil servants & 0 & 0 & 1 & 6 \\
\hline \multicolumn{5}{|l|}{ Level Education } \\
\hline Junior high school & 1 & 6 & 0 & 0 \\
\hline Senior High School & 9 & 56 & 10 & 62 \\
\hline Bachelor & 6 & 38 & 4 & 25 \\
\hline Diploma & 0 & 0 & 2 & 13 \\
\hline \multicolumn{5}{|c|}{ Consumption of pain medications } \\
\hline No & 16 & 100 & 16 & 100 \\
\hline \multicolumn{5}{|l|}{ Degree of Perineal Injury } \\
\hline Degree 1 & 0 & 0 & 0 & 0 \\
\hline Degree 2 & 13 & 81 & 14 & 87 \\
\hline Degree 3 & 3 & 19 & 2 & 13 \\
\hline
\end{tabular}

Tabel 2. Effectiveness of Pain Intensity Reduction between Cold Compress and Lavender Aromatherapy $(n=32)$

\begin{tabular}{|c|c|c|c|c|c|c|c|c|}
\hline \multirow{3}{*}{ Pain Intensity Scale } & \multicolumn{4}{|c|}{ Cold compress $(n=16)$} & \multicolumn{4}{|c|}{ Lavender Aromatherapy $(n=16)$} \\
\hline & \multicolumn{2}{|c|}{ Pretest } & \multicolumn{2}{|c|}{ Posttest } & \multicolumn{2}{|c|}{ Pretest } & \multicolumn{2}{|c|}{ Posttest } \\
\hline & $\mathbf{n}$ & $\%$ & $\mathbf{n}$ & $\%$ & $\mathbf{n}$ & $\%$ & $\mathbf{n}$ & $\%$ \\
\hline Mild pain & 2 & 12 & 12 & 75 & 2 & 12,5 & 7 & 44 \\
\hline Moderate pain & 11 & 69 & 4 & 25 & 12 & 75 & 9 & 56 \\
\hline Controlled severe pain & 3 & 19 & 0 & 0 & 2 & 12,5 & 0 & 0 \\
\hline Wilcoxon Signed Rank Test & \multicolumn{4}{|c|}{$\mathrm{p}=0.000$} & \multicolumn{4}{|c|}{$\mathrm{p}=0.008$} \\
\hline Mean & \multicolumn{4}{|c|}{19.00} & \multicolumn{4}{|c|}{14.00} \\
\hline Sum & \multicolumn{4}{|c|}{304.00} & \multicolumn{4}{|c|}{224.00} \\
\hline Mann-Whitney U Test & \multicolumn{8}{|c|}{$\mathrm{p}=0.077$} \\
\hline
\end{tabular}


The results of table 1 show that from the two groups, the majority of respondents were aged between 26-30 years. Respondents with the characteristics of work in the cold compress group, the majority of respondents work as a private, while in the lavender aromatherapy group, the majority of respondents work as housewives. The majority of respondents were educated last high school in the two groups. All respondents had never taken pain medication in either the cold compress group of lavender aromatherapy. The majority of respondents experienced second-degree perineal injury between the two groups.

Based on table 2 above of 16 postpartum mothers before giving cold compresses who felt perineal pain with a mild pain scale of 2 people (12\%) who felt moderate pain as many as 11 people (69\%) and those who felt severe pain was controlled as many as three people (19\%), whereas after administration of cold compresses patients who felt perineal pain with a mild pain scale of 12 people $(75 \%)$ and who felt moderate pain four people $(25 \%)$. From the results of the Wilcoxon Signed Rank Test statistic, a significant result $=0.000<0.05$, which means that there is an influence of giving a cold compress to decrease the intensity of postpartum perineal pain. While from 16 patients who experienced postpartum perineal pain before giving lavender aromatherapy who experienced a mild pain scale of 2 people (12.5\%), who experienced moderate pain as many as 12 people (75\%), and who experienced severe pain controlled by two people (12.5\%), whereas after giving lavender aromatherapy, there were seven patients (44\%) with mild pain scale patients with postpartum perineum pain and nine people who had moderate pain (56\%). From the results of the Wilcoxon Signed Rank Test statistic, a significant result $(\alpha$ calculation $)=0.008<0.05$, which means that there is an influence of giving cold compresses to decrease the intensity of postpartum perineal pain. Based on mean rank data after a cold compress is 19.00 while for aromatherapy lavender mean rank is 14.00 . The Mann Whitney statistical test results obtained a signed value of 2 tailed $\mathrm{p}=0.077$, which is greater than 0.05 so that $\mathrm{H} 1$ is rejected, meaning that there is no difference in the decrease in pain intensity between the cold compress and lavender aromatherapy groups. However, the results of the Wilcoxon sign test cold compress test obtained $\mathrm{p}$ value $=0.000$, and the results of the Wilcoxon sign test of lavender aromatherapy obtained pvalue $=0.008$.

\section{DISCUSSIONS}

Perineal pain in the puerperal mother is caused by a tear in the area during labor. Perineal wound pain can be interpreted when a mother feels pain due to injury to the perineal area after going through the process of the birth of her baby (Mahishale, et al., 2013). Pain can occur due to spontaneous tears or episiotomy of the perineum. The intensity of pain felt by each individual will be different (Judha et al., 2012). The level of pain rating scale can be divided into five categories, namely no pain, mild pain, moderate pain, severe pain, and very severe pain. Pain can be controlled by two methods, namely pharmacological and non-pharmacological. Pharmacological pain relief methods are pain relief methods using chemical drugs, including administering inhalation analgesics, opioids analgesics, and regional anesthesia, while nonpharmacological methods are natural pain relief methods without using chemical drugs using cold compresses and lavender aromatherapy (Salamati et al., 2014).

The manifestation of cold compresses is the release of endorphins, which blocks the transmission of larger and faster sensory A-beta nerve fibers. This process decreases pain transmission through $\mathrm{C}$ fibers and delta-A with a small diameter, so that the gates of the synapses block the transmission of pain impulses. Endorphin is a substance such as morphine produced by the body (including endogenous 
chemicals) and has a strong concentration in the nervous system. This endorphin functions as an inhibitor of pain transmission by blocking the transmission of brain impulses and the spinal cord (Mohamed et al., 2012). Cold compresses are used to relieve pain by slowing the speed of nerve conduction, causing numbness and working as a counterirritant. Giving cold application action can reduce pain and increase healing. Cold application is related to the slowing ability of pain nerves in channeling pain stimuli (Sulistyawati, 2009). The cold application can reduce the temperature of the diseased area, limit blood flow, and prevent fluid from entering the tissues around the wound. This will reduce pain and swelling. The cold application can reduce the sensitivity of nerve endings resulting in an increase in the pain threshold. The cold application will also reduce tissue damage by reducing local metabolism, so that tissue oxygen demand decreases. Neuro-hormonal response to cold therapy, according to Novita Intan (Ai Yeyeh et al., 2010). The effect of cold compresses on postpartum perineal pain decreased in mean total pain intensity by 19.00 , where 11 respondents had moderate pain, three respondents had severe pain, and two respondents had mild pain after being given intervention with cold compresses, 12 respondents had fallen into pain mild, and four respondents fell into moderate pain.

While other non-pharmacological therapies are giving aromatherapy lavender. The mechanism of action of lavender aromatherapy is lavender aromatherapy containing linalyl acetate and linalool that is inhaled into the nose is captured by the olfactory bulb and then entered through the olfactory canal into two, lateral and non-medial sides. On the lateral side, this channel sneaks into the third neuron in the amygdala, seminular gyrus, and ambiens gyrus, which is part of the limbic. The medial sideline also ends in the limbic system. Limbic is part of the brain, shaped like the letter $\mathrm{C}$ as a center where memory, mood, and intelligence enter. In the limbic part, the amygdala is responsible for our emotional response to its aroma. After limbic aromatherapy stimulates exposure to encephalin or endorphins to the hypothalamus gland, and ventromedial rostral medulla (Stea et al., 2014). Aromatherapy Lavender has bactericidal, analgesic, and antidepressant, antispasmodic properties when aromatherapy is inhaled, the substances contained in it will stimulate the hypothalamus to release endorphin hormones because it can make substances that are relaxed and calm also active in the form of linalool and linalyl acetate in the effects of lavender as an analgesic (Pratiwi et al., 2012). The influence of lavender aromatherapy on postpartum perineal pain decreased the mean total pain intensity by 14.00, in which 12 respondents were at the beginning of moderate pain, two respondents were in severe pain, and two respondents were in mild pain after being given intervention with lavender aromatherapy, nine respondents fell into pain moderate, and seven respondents fell into mild pain.

The results of this study indicate that there is no significant difference between cold compresses and lavender aromatherapy, cold compresses are a physical therapy modality that uses cold physical properties to treat various conditions, including perineal wound pain. Cold compresses work by stimulating the surface of the skin to control pain. Cold therapy given will affect the impulses carried by tactile A-beta fibers to dominate more so that the "gate" will close, and the impulse of pain will be blocked. Pain that is felt will decrease or disappear for a while (Purwaningsih and Rahayu, 2015). The purpose of cold compresses is to reduce inflammation that occurs at the site of the pain so that the patient's pain sensation can be reduced. While the reduction in pain with aromatherapy lavender refers to the concept of gate-control which lies in the physiology of the mechanism of delivering impulses of pain that occurs when the defense 
system is opened, and conversely the delivery of pain impulses can be inhibited when the defense system is closed (Woollard et al., 2009). Lavender aromatherapy is an attempt to close the defense system. In addition, lavender aromatherapy affects the smooth circulation of blood, so that an adequate supply of nutrients to the wound tissue and the healing process will be faster. When aromatherapy is inhaled, the active substance contained in it will stimulate the hypothalamus (pituitary gland) to secrete endorphins. Endorphins are known as substances that cause calm, relaxed, and happy. In addition, the active substances in the form of linalool and linalyl acetate contained in lavender have analgesic effects (Karlina et al., 2015).

This research is supported by previous studies that there are significant results in the administration of cold compresses against pain in the perineal wound (Ersila et al., 2019). In a previous study conducted by (Vardanjani et al. (2012), it was found that there was a very significant change in the level of pain after cold compresses were performed in the first hour and 24 hours.

If someone has experienced the same pain, then the pain threshold of that person tends to be lower than the pain threshold that was felt at first. In postpartum mothers, the experience can be related to mothers' experiences in the process of pregnancy, childbirth, and postpartum. Postpartum multipara mothers will certainly have a lower pain threshold compared to primiparous postpartum mothers because multipara mothers have more experience in adapting to pain than in primiparous mothers (Moloku and Sambeka, 2013). The mother's ability to adapt to pain is also crucial. There are mothers who have a high pain threshold so that when they experience the firstdegree laserasiperineum it is very painful. Conversely, some mothers actually experience degree 2 laceration but do not complain of very painful pain in the perineum because the maternal pain threshold is low, where the ability to adapt to the pain is quite good (Susilawati and Ilda, 2019).

Coping affects a person's ability to treat pain. Someone who controls pain with an internal locus feels that they have the ability to deal with pain. Conversely, someone who controls pain with an external locus is more likely to feel that other factors in his life, such as nurses, are responsible for the pain he feels. Therefore, patient coping is very important to consider (Suryati et al., 2013).

\section{CONCLUSIONS}

This research is expected to improve the ability of respondents to control pain independently so that it does not depend on the use of pharmacological therapy and can be used as an intervention in an effort to provide services and interventions to reduce perineal pain. Further research is needed to determine the effect of cold compresses and lavender aromatherapy on other pain relief by adding the duration of time for interventions so that the results obtained are more optimal.

\section{REFERENCES}

Ambarwati, E, R, Diah, W. (2010). Asuhan Kebidanan Nifas. Yogyakarta: Nuha Medika.

Depkes RI. (2013). Riset Kesehatan Dasar. Jakarta: Badan Penelitian dan pengembangan Kesehatan Kementrian Kesehatan RI.

Ersila, Wahyu, Lia Dwi Prafitri, and Nina Zuhana. 2019. Perbedaan Efektivitas Massage Efflurage Dan Kompres Dingin Terhadap Nyeri Persalinan Di Puskesmas Kabupaten Pekalongan. Jurnal SIKLUS. Volume 08 Nomor 02 , Juni 8: 107-15.

Judha M, Afroh F, Sudarti. (2012). Teori Pengukuran Nyeri \& Nyeri Persalinan, Nuha Medika: Yogyakarta. 
Karlina SD, Reksohusodo S, Widayati A.( 2015). Pengaruh Aromaterapi Lavender secara Inhalasi terhadap Penurunan Intensitas Nyeri Persalinan Fisiologis pada Primipara Inpartu Kala Satu Fase Aktif di BPM Fetty Fathiyah Kota Mataram. Maj Kesehat Fak Kedokt Univ Brawijaya;2(2).

Kartika R, Susilo J, Lestari P. ( 2015). Efek Lilin Aromaterapi Lavender Terhadap Perubahan Intensitas Nyeri Persalinan Normal Kala I Fase Aktif. ejurnal Ngudi Waluyo.;7(24).

Mahishale, et al. (2013). Effect of Therapeutic Ultrasound and Maternal Cooling Gel Pad for Perineal Pain Following Vaginal Delivery with Episiotomy. $J$ Women's Health Care, 2:3.

Mohamed, Hoda Abed El-Azim \& Nahed Saied El-Nagger. (2012). Effect of Self Perineal Care Instructions on Episiotomy Pain and Wound Healing of Postpartum Women. Journal of American Science, 2012;8(6).

Moloku, F., \& Sambeka, B. W. J. (2013). Hubungan Pengetahuan Tentang Perawatan Dengan Penyembuhan Luka Episiotomi Pada Ibu Post Partum di Ruangan Irina D Bawah RSUP Dr. R.D. Kandou Malalayang. Ejournal Keperawatan (E-Kp), 1(1).

Mulati, T., S \& Dewi Susilowati. (2018). Pengaruh Derajat Robekan Perineum Terhadap Skala Nyeri Perineum Pada Ibu Nifas Di Kabupaten Wonogiri. Jurnal Kebidanan Dan Kesehatan Tradisional, Volume 3(1), 1-56.

Oliveira, Sonia M.J.V. Silva, Flora M.B. Riesco, Maria L.G. Latorre, Maria do Rosario D.O. Nobre, Moacyr R.C.. (2012). Comparison of Application Times for Ice Packs Used to Relieve Perineal Pain after Normal Birth: A Randomised Clinical Trial. Journal of Clinical Nursing, Hoboken, Volume 21(1), 23-24.

Pratiwi R, Ermiati, Widiasih R.(2012). Penurunan Intensitas Nyeri Akibat Luka Post Sectio Caesarea Setelah Dilakukan latihan Teknik Relaksasi Pernapasan Menggunakan Aromaterapi Lavender di Rumah Sakit Al Islam Bandung. Students e-journals;1(1):1-15.

Prawirohardjo, S. (2009). Ilmu kebidanan. Jakarta : Bina Pustaka Sarwono Prawirohardjo.

Purwaningsih AA, Rahayu. (2015). Efektivitas kompres hangat dan kompres dingin untuk mengurangi laserasi perineum Nyeri pada primipara di Candimulyo Magelang Jurnal Penelitian Internasional dalam Ilmu Kesehatan. Desember 2015, Vol 3.

Rukiah yeyeh ai, yulianti lia, maemunah, susilawati lilik. (2010). Asuhan Kebidanan 1. Jakarta: CV. Trans Info Media.

Salamati A, Mashouf S, Sahbaei F, Mojab F.(2014). Effects of Inhalation of Lavender Essential Oil on Open-heart Surgery Pain. Iran J Pharm Res IJPR ;13(4):1257-61.

Stea S, Beraudi A, De Pasquale D. (2014). Essential Oils for Complementary Treatment of Surgical Patients: State of the Art. Evidence-Based Complement Altern Med. ;2014:1-6.

Steen, Mary Marchand, Paul. (2007). Ice Packs and Cooling Gel Pads Versus No Localised Treatment for Relief of Perineal Pain: a Randomised Controlled Trial. Evidence Based Midwifery. Volume 5 (1): 16-22.

Sulistyawati, Ari. (2009). Buku Ajar Asuhan Kebidanan pada Ibu Nifas. Yogyakarta: CV. Andi Offset.

Suryati, Yayat; Kustati, Eni; Hastuti, W. (2013). Hubungan Tingkat Pengetahuan Ibu Nifas Tentang Perawatan Luka Perineum Dan Status Gizi Dengan Proses Penyembuhan Luka. Jurnal Manajemen Keperawatan, 1(1), 25-32.

Susilawati, E., \& Ilda, W. R. (2019). Efektifitas Kompres Hangat dan Kompres Dingin Terhadap Intensitas Nyeri Luka Perineum Pada Ibu Post Partum di BPM Siti Julaeha 
Jurnal INJEC Vol. 5 No. 1 June 2020: 51-59

Pekanbaru. JOMIS (Journal Of Midwifery Science), 3(1), 7-14.

Vardanjani, S. A. E., Shafai, F. S., Mohebi, P., Deyhimi, M., Delazar, A Ghojazadeh, M., \& Malekpour, P. (2012). Wound healing Benefits of Curcumin for Perineal Repair after Episiotomy: Results of an Iranian
Randomized Controlled Trial. Life Science Journal, 9(4), 5536-5541.

WHO. (2015). General information program and health profile. Washington DC: WHO.

Woollard AC, Tatham KC, Barker S.( 2009) The influence of essential oils on the process of wound healing: a review of the current evidence. J Wound Care. Jun;16(6):255-7. 